\title{
CHANGES OCCURRING IN THE MACROPHAGE SYSTEM OF THE LUNGS IN PNEUMOCOCCUS LOBAR PNEUMONIA ${ }^{1}$
}

\author{
BY O. H. ROBERTSON AND C. G. UHLEY \\ (From the Department of Medicine and the Douglas Smith Foundation for Medical Research of \\ the University of Chicago and the Pathological Laboratory of the Minneapolis General \\ Hospital)
}

(Received for publication October 9, 1935)

In our study of the pathology of experimentally induced lobar pneumonia in the dog $(1,2)$ certain striking changes in the architecture of the lung parenchyma and the character of the cellular exudate were observed to occur regularly at the time of recovery. These changes consisted of an initial thickening of the alveolar walls due principally to an increase in the number and size of the large mononuclear septal cells and a subsequent liberation of these cells into the air spaces where they assumed the functions of the free histiocyte or macrophage. The newly mobilized macrophages were actively phagocytic, taking up polymorphonuclear leukocytes, red blood cells and pneumococci, and soon became the predominant cells of the rapidly thinning intra-alveolar exudate. Pneumococci diminished in numbers or disappeared entirely in such areas. This process was always found accompanying resolution.

The similarities observed between the pathogenesis of the experimental pulmonary lesion and that of clinical lobar pneumonia (3) suggested that regression of the two lesions might also occur in the same manner. In order to investigate this phase of the disease in human beings, a study was made of autopsy material from cases of lobar pneumonia in whom the age of the various lobe lesions had been determined during life by serial $x$-rays. It was hoped thereby to obtain as complete a picture as is possible from postmortem material of the changes occurring in the inflammatory process during the various stages of the infection.

The occurrence of large mononuclear cells in the exudate of the consolidated lung in lobar pneumonia was described many years ago. Pratt (4) in 1900 gave an excellent account of the changes in the cellular picture

1 Reported in abstract form in the Proceedings of the Society for Experimental Pathology; Arch. Path., 1933, $16,305$. observed through the different stages of the disease. He described two types of mononuclear cell, one resembling the transitional leukocyte, which was present only in the early lesion; the other a large phagocytic cell occurring late in the disease. The former he considered as probably coming from the blood; the latter as arising from the alveolar walls which showed marked proliferation of the "alveolar epithelium." Pratt also observed these same large phagocytic cells in the hilum lymph nodes. He states further that after the 9th day of the disease "desquamated epithelial cells" were frequently found predominating in the exudate. Mallory (5) observed the appearance of "endothelial leukocytes" in large numbers at times in the stage of resolution. Most pathologists since have paid relatively little attention to these large mononuclear phagocytic cells in the pneumonic exudate, and when mentioned, they have been designated as desquamated epithelial cells. Loeschcke (6) describes such cells as replacing the polymorphonuclear leukocytes of the exudate in the late stage of the disease and assigns to them the function of removal of the fibrin.

Recently, however, two investigators, Fried $(7,8)$ and Costa (9), have called attention to the prominence of the macrophages in the process of resolution in lobar pneumonia. Fried has also described the progressive mobilization of macrophages in experimental allergic inflammation of the lungs. His inferences concerning the important rôle played by the lung macrophages in the body's defense against pathogenic microorganisms are based chiefly on his studies in experimental infection with the tubercle bacillus. Costa's study deals directly with the changing cellular picture in the human pneumonic process. By means of vital stains of tissues obtained 1 to 2 hours after death he was able to distinguish two types of mononuclear cells appearing in the intra-alveolar exudate of the older lesions, one which he identified as a monocyte, and the other as a histiocyte or macrophage. The relative numbers of these cells, especially the macrophages, increase toward the terminal stages of the disease. Their origin he ascribes to the local septal cells, an increase in the number of which produces a thickening of the alveolar walls. He postulates a relationship between this mononuclear transformation in the lungs and the crisis in pneumonia, but gives no bacteriological or immunological data. No detailed observations on the relation of the macrophages to the distribution of pneumococci in the lesions of lobar pneumonia have been reported. Several writers state that pneumococci become fewer as the disease progresses, and Loeschcke did ob- 
serve that they disappeared with the replacement of polymorphonuclear leukocytes by "desquamated epithelial cells" but makes no comments on the possible antipneumococcal activity of these cells.

\section{MATERIALS AND METHODS}

The pathological material was provided by 40 cases of pneumococcus lobar pneumonia in adults dying at intervals of from 6 to 12 hours to two months after the onset of the disease, and eight cases of pneumonia due to other microorganisms. All but 4 of these patients were studied at the University of Chicago Clinics and the Minneapolis General Hospital. Specimens from three cases were sent us from the Hospital of the University of Minnesota and one from the Hospital of the Rockefeller Institute. ${ }^{2}$ The Type Pneumococcus was determined during life in most instances, and by culture of the lungs after death. They included Types I, II, and III and Group IV. The age of the lesions in the different parts of the lung were determined, first, by history of onset of disease for the dating of the initial process,

${ }^{2}$ We are much indebted to Dr. Hobart Reimann of the University of Minnesota and Dr. Edward E. Terrell of the Rockefeller Institute for the material from these carefully worked up cases. and second, by serial $\mathbf{x}$-rays for the detection of secondary lesions. ${ }^{8}$ Daily $x$-rays from the time of admission until death were made in twenty-three of the cases. Most of the other patients had only a single $x$-ray. In some of the early fatal cases no $x$-rays were made. In addition to $\mathbf{x}$-rays, daily physical examinations of the lungs were recorded in most instances. None of the cases included in the series had been treated with immune serum. The lesions classified by age in Table I included only those which could be dated to within 24 hours. In more than half the series daily observations on bacteremia and immune substances were made. Descriptions were recorded of the gross appearance of the different areas of the lung from which the sections were taken. Large pieces of tissue 3 to $4 \mathrm{~cm}$. in diameter were removed; often 2 or 3 from a single lobe, depending on the variations in the appearance of the cut surface. The tissue was fixed in Zenker's solution containing $\mathbf{5}$ per cent acetic acid and embedded in paraffin. They were stained with a modified Gram Weigert technique devised by Mrs. $\mathrm{H}$. M. Wallace (11) which brings out clearly the cell structure and boundaries as well as the microorganisms.

3 In about half the cases in which serial $\mathbf{x}$-rays were made, stereoscopic films were obtained by means of a special apparatus devised by Hodges and Lipscomb (10).

TABLE I

Time of development of macrophage reaction

\begin{tabular}{|c|c|c|c|c|c|c|c|c|c|c|c|c|}
\hline & \multirow{2}{*}{ Age of lesion } & \multirow{2}{*}{$\begin{array}{l}\text { Total } \\
\text { number } \\
\text { of lobe } \\
\text { lesions }\end{array}$} & \multicolumn{2}{|c|}{$\begin{array}{l}\text { Predominant cell } \\
\text { in alveolar exudate }\end{array}$} & \multicolumn{3}{|c|}{$\begin{array}{c}\text { Macrophage } \\
\text { reaction }\end{array}$} & \multicolumn{3}{|c|}{$\begin{array}{l}\text { Number of } \\
\text { pneumococci }\end{array}$} & \multicolumn{2}{|c|}{$\begin{array}{c}\text { State of } \\
\text { pneumococci }\end{array}$} \\
\hline & & & $\begin{array}{c}\text { Poly- } \\
\text { morpho- } \\
\text { nuclear }\end{array}$ & $\begin{array}{c}\text { Macro- } \\
\text { phage }\end{array}$ & None & $\underset{\text { ning }}{\text { Begin- }}$ & $\begin{array}{c}\text { Well } \\
\text { devel- } \\
\text { oped }\end{array}$ & Many & Few & $\begin{array}{l}\text { Ab- } \\
\text { sent }\end{array}$ & $\begin{array}{c}\text { Mostly } \\
\text { free }\end{array}$ & $\begin{array}{l}\text { Mostly } \\
\text { intra- } \\
\text { cellular }\end{array}$ \\
\hline $\begin{array}{l}\text { Cases dying } \\
\text { early }\end{array}$ & $\begin{array}{l}6 \text { to } 21 \text { hours } \\
24 \text { to } 48 \text { hours }\end{array}$ & $\begin{array}{l}2 \\
1\end{array}$ & $\begin{array}{l}2 \\
1\end{array}$ & 0 & 2 & $\begin{array}{l}0 \\
1\end{array}$ & 0 & $\begin{array}{l}2 \\
1\end{array}$ & 0 & 0 & 1 & $\begin{array}{l}1 \\
1\end{array}$ \\
\hline $\begin{array}{l}\text { Lesions } \\
\text { (lobes) } \\
\text { during } \\
\text { active } \\
\text { stage of } \\
\text { disease }\end{array}$ & $\begin{array}{l}1 \text { st } 24 \text { hours } \\
1 \text { to } 2 \text { days } \\
2 \text { to } 3 \text { days } \\
3 \text { days } \\
4 \text { days } \\
5 \text { days } \\
6 \text { days } \\
7 \text { days } \\
8 \text { days } \\
9 \text { days } \\
10 \text { days } \\
11 \text { to } 12 \text { days }\end{array}$ & $\begin{array}{r}11 \\
5 \\
5 \\
6 \\
9 \\
8 \\
6 \\
11 \\
5 \\
6 \\
7 \\
4\end{array}$ & $\begin{array}{l}9 * \\
5 \\
5 \\
6 \\
9 \\
8 \\
4 \\
9 \\
4 \\
3 \\
0 \\
1\end{array}$ & $\begin{array}{l}2 \\
0 \\
0 \\
0 \\
0 \\
0 \\
2 \\
2 \\
1 \\
3 \\
7 \\
3\end{array}$ & $\begin{array}{l}7 \\
2 \\
5 \\
4 \\
5 \\
3 \\
2 \\
4 \\
2 \\
0 \\
0 \\
1\end{array}$ & $\begin{array}{l}4 \ddagger \\
3 \\
0 \\
2 \\
4 \\
4 \\
2 \\
5 \\
2 \\
3 \\
0 \\
0\end{array}$ & $\begin{array}{l}0 \\
0 \\
0 \\
0 \\
0 \\
1 \\
2 \\
2 \\
1 \\
3 \\
7 \\
3\end{array}$ & $\begin{array}{l}7 \\
5 \\
5 \\
6 \\
9 \\
5 \\
3 \\
8 \\
3 \\
3 \\
0 \\
18\end{array}$ & $\begin{array}{l}\mathbf{4} \\
\mathbf{0} \\
\mathbf{0} \\
\mathbf{0} \\
\mathbf{0} \\
\mathbf{3} \\
\mathbf{2} \\
\mathbf{2} \\
\mathbf{1} \\
\mathbf{3} \\
\mathbf{2} \\
\mathbf{3}\end{array}$ & $\begin{array}{l}0 \\
0 \\
0 \\
0 \\
0 \\
0 \\
1 \\
1 \\
1 \\
0 \\
5 \\
0\end{array}$ & $\begin{array}{l}9 \\
1 \\
0 \\
2 \dagger \\
0 \\
1 \S \\
0 \\
0 \\
0 \\
0 \\
0 \\
0\end{array}$ & $\begin{array}{r}2 \\
4 \\
5 \\
4 \\
9 \\
7 \\
5 \\
10 \\
4 \\
6 \\
2 \\
4\end{array}$ \\
\hline $\begin{array}{l}\text { Lesions after } \\
\text { recovery }\end{array}$ & $\begin{array}{l}1 \text { to } 2 \text { weeks after } \\
\text { recovery } \\
1 \text { to } 2 \text { months after } \\
\text { recovery }\end{array}$ & $\begin{array}{l}3 \text { I } \\
3 \text { I }\end{array}$ & $\begin{array}{l}0 \\
1 \|\end{array}$ & $\begin{array}{l}3 \\
2\end{array}$ & $\begin{array}{l}0 \\
0\end{array}$ & $\begin{array}{l}0 \\
0\end{array}$ & $\begin{array}{l}3 \\
3\end{array}$ & $\begin{array}{l}0 \\
0\end{array}$ & $\begin{array}{l}1 \\
0\end{array}$ & $\begin{array}{l}2 \\
3\end{array}$ & 0 & 1 \\
\hline
\end{tabular}

* One of these lesions showed more red blood cells than polymorphonuclears.

$\dagger$ These two lesions were from a patient dying at the end of 3 days.

$\$$ Reaction very slight and focal in distribution.

Macrophage reaction absent.

Recently established bronchopneumonia due to streptococcus and staphylococcus.

Three cases. 


\section{The macrophage reaction}

Early in the study it became evident that with the advancing age of the pneumonic lesion there occurred changes in the histology of the lung parenchyma and cellular exudate analogous to those observed in the experimental canine process approaching the stage of resolution. The evolution of this cellular transformation could frequently be observed in lesions of different age in a single case. Microphotographs shown in Figures 1 to 4 , made from sections of lesions varying from 2 to 3 days to 9 days old in a case of Type III pneumococcus lobar pneumonia, illustrate the several stages in the development of the macrophage reaction as observed in the human being. The first evidence of the reaction consists of an increase in the number of large mononuclear cells in the alveolar walls, many of which protrude into the air space (Figure 2). This results in a thickening of the septa. A comparison of Figure 1, which shows the typical appearance of the red-gray stage of hepatization of a lesion 2 to 3 days old, with Figure 2, taken from a 3 to 4 day process showing a beginning macrophage reaction, reveals clearly the characteristic change in structure. At this early stage the intra-alveolar cellular exudate is predominantly polymorphonuclear in character. As the process develops the large mononuclear cells become detached from the alveolar wall and enter the exudate where the majority of them exhibit the appearance and phagocytic functions of the macrophage (Figure 3$).{ }^{4}$ These cells gradually replace the polymorphonuclears, the total number of cells composing the exudate diminishes, the fibrin disappears progressively, and open space begins to appear in the air sacs. This stage is represented in Figure 4 taken from the initial lesion which began nine days before death. The perivascular accumulation of mononuclear cells which composed a conspicuous feature of the macrophage reaction in the dog was found in the human lung only occasionally and to a slight degree. Mitotic figures were seldom en-

4 While we have not made a study of the vitally stained cells in the pneumonic exudate in human lobar pneumonia, such observations have been carried out in the experimental canine disease. It was found that the majority of the large mononuclears in the resolving exudate were true macrophages (2). countered either in the human or the canine lesions. No differences in cellular response could be detected between the several types of pneumococcus pneumonias.

The same type of tissue cell reaction was observed in the lymph glands at the hilum of the lung. The development of the process cannot be followed as easily in this site as in the lung parenchyma, but when well developed it exhibits a striking picture (Figure 5). The dilated sinuses contain large numbers of typical macrophages and many other smaller mononuclear cells. Large mononuclear cells can be observed attached to the walls of the sinuses and also frequently in the midst of the lymphoid tissue. In several instances a definite macrophage reaction was observed in the lymph node at the hilum of a lobe which showed very little or no response of the macrophages in the lung parenchyma.

\section{The stage of the inflammatory process at which the macrophage reaction occurs.}

\section{Relation to resolution}

In order to determine the time at which the macrophage reaction tends to occur in the development of the pathological process, all the lesions by lobes, of approximately known age were grouped as shown in Table I. This tabulation comprises 91 lesions occurring in 40 individual cases. Many other lesions in these and other cases could not be included because of lack of adequate data as to age. Furthermore, unless one stage of the pathological process was found to predominate in the lesion, it was not included in the tabulation.

It was found that the appearance of the macrophage reaction was not confined to any one stage of the disease, but in lesions up to the fourth day the reaction was relatively slight in degree and occurred in a smaller percentage of the lesions than after this period. Two patients dying within 24 hours showed no reaction of the macrophages while in one dying within less than 48 hours there was a beginning reaction. Of the metastatic lesions developing within 24 hours of death, 4 of a total of 11 showed a beginning macrophage reaction, but this was very slight and focal in character. In 25 lesions of from 1 to 4 days of age, a beginning reaction of the macrophages was detected in 11 . None showed a well developed 


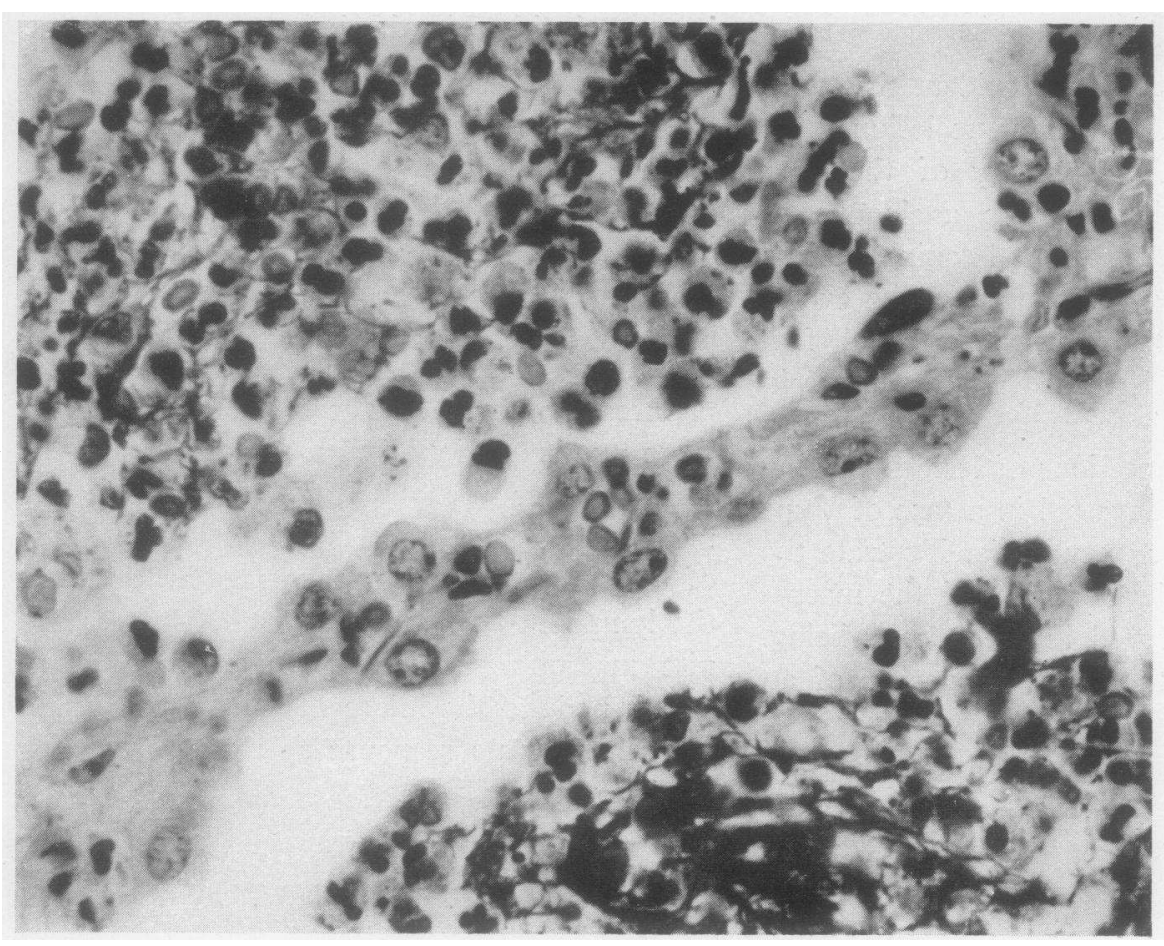

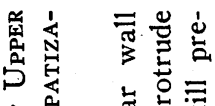

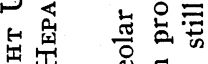

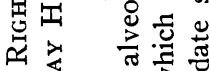

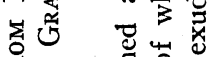

要

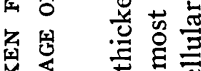

运

证

凅 兽

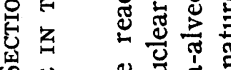

电 思

出出参

io

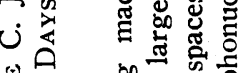

要古 Uీ용. ن ${ }^{m}$ \&

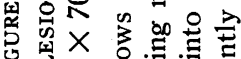
至

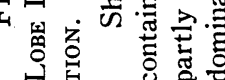

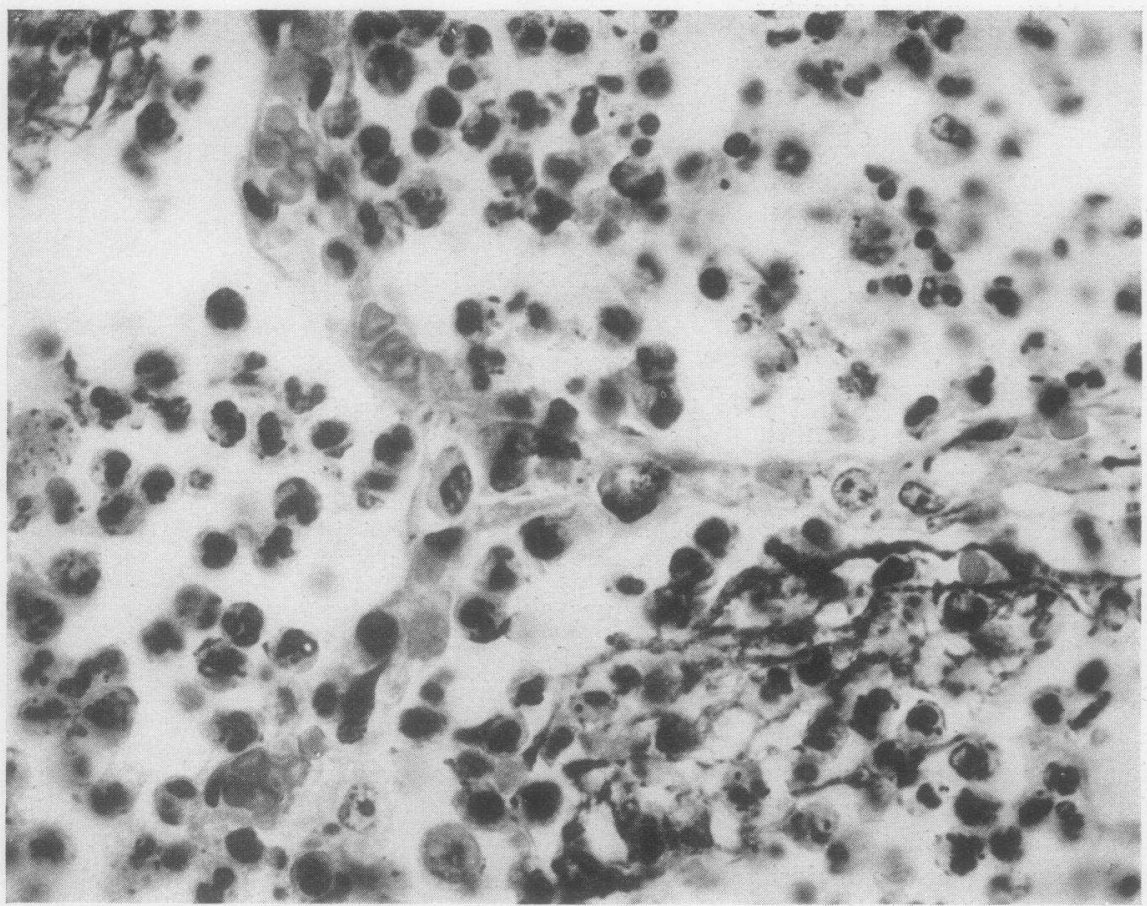

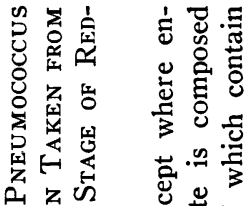

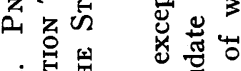

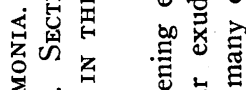

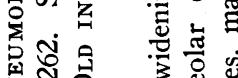

政

艁

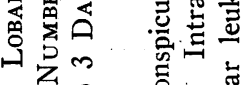

地

政

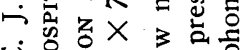

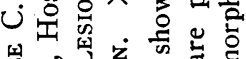

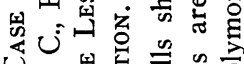

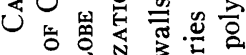
- म中

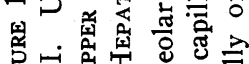

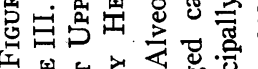

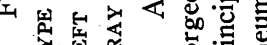

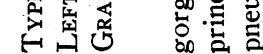




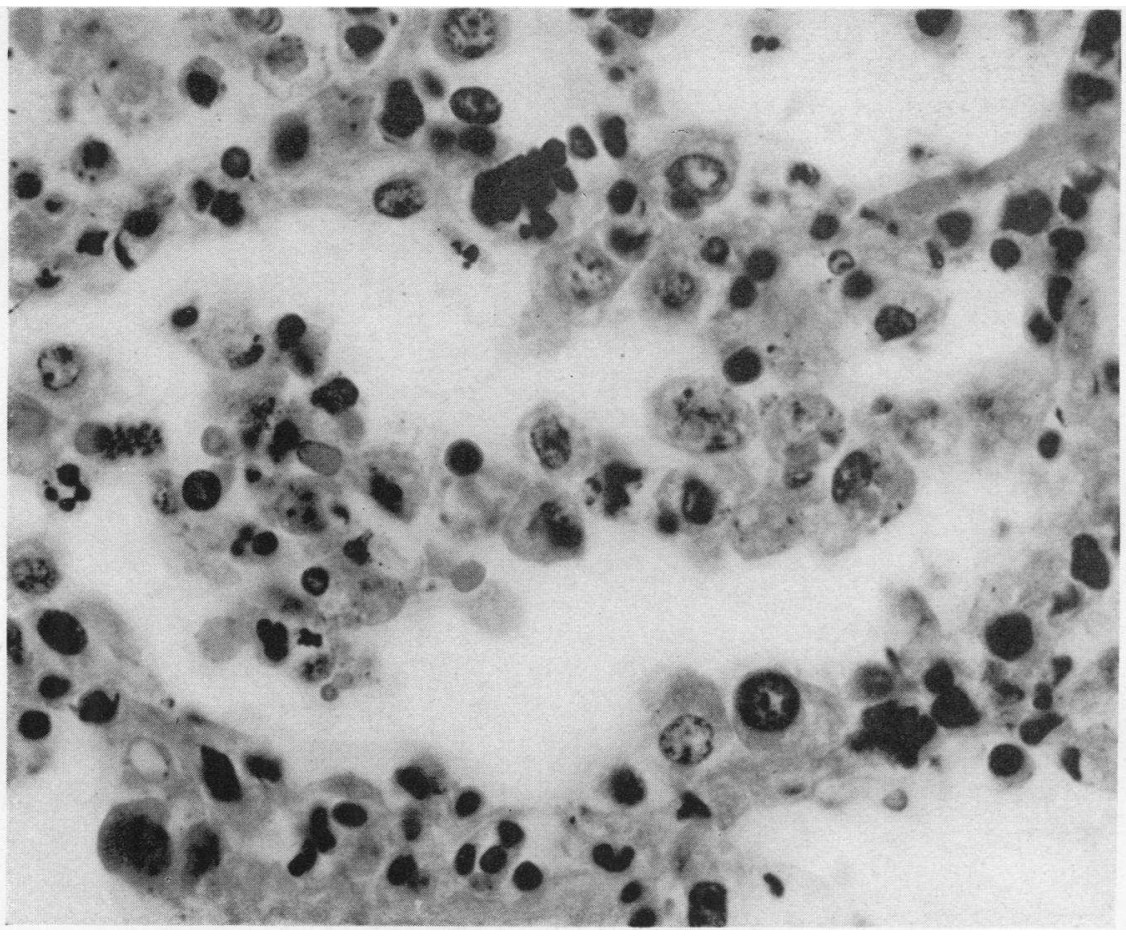

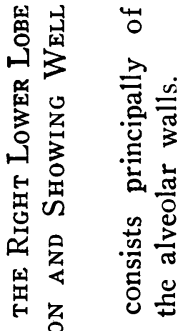

范 8 iั

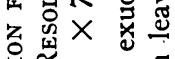

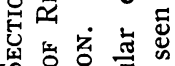
出的资 원 出氙界

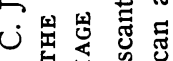
四

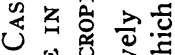
界界

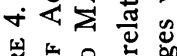

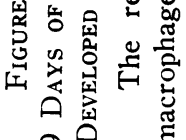
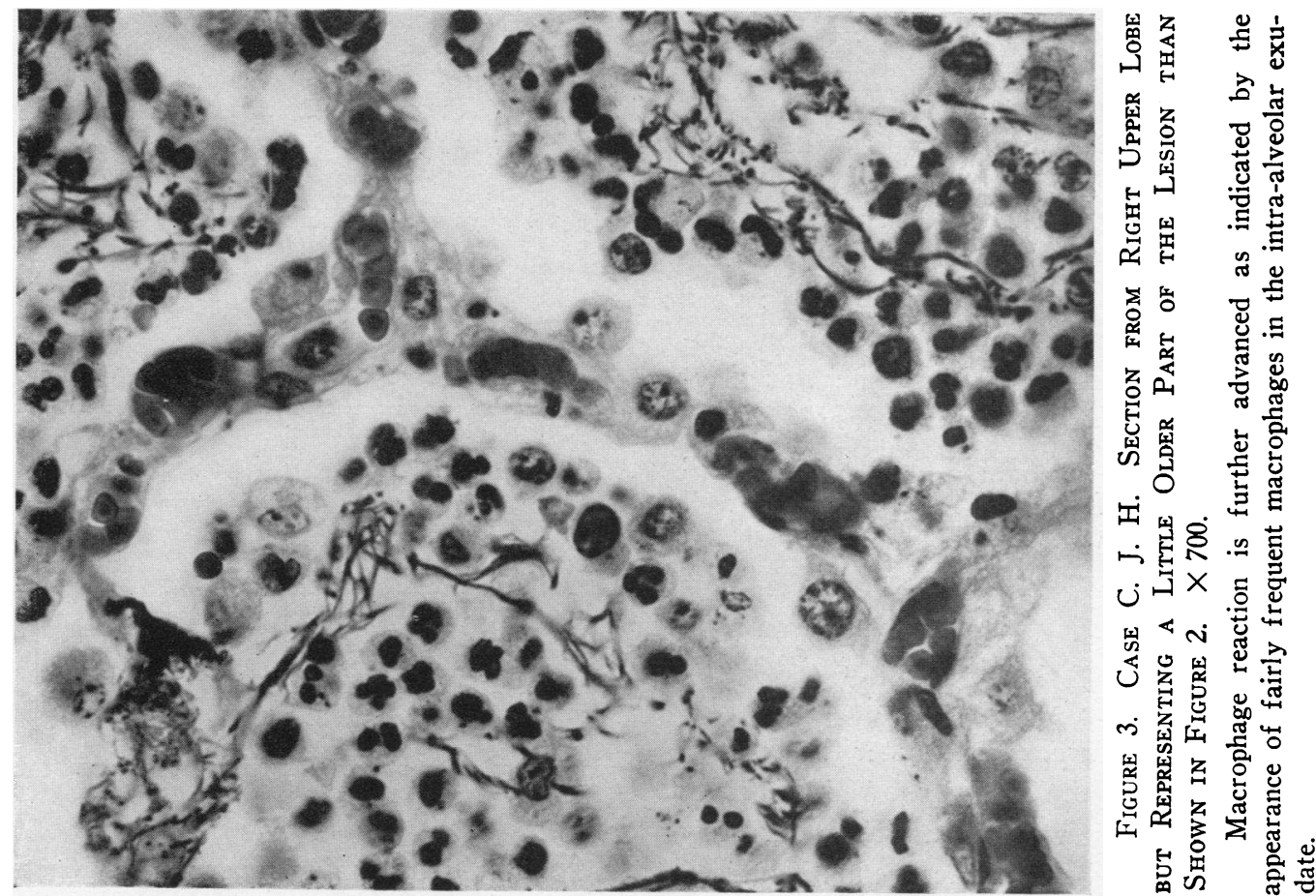


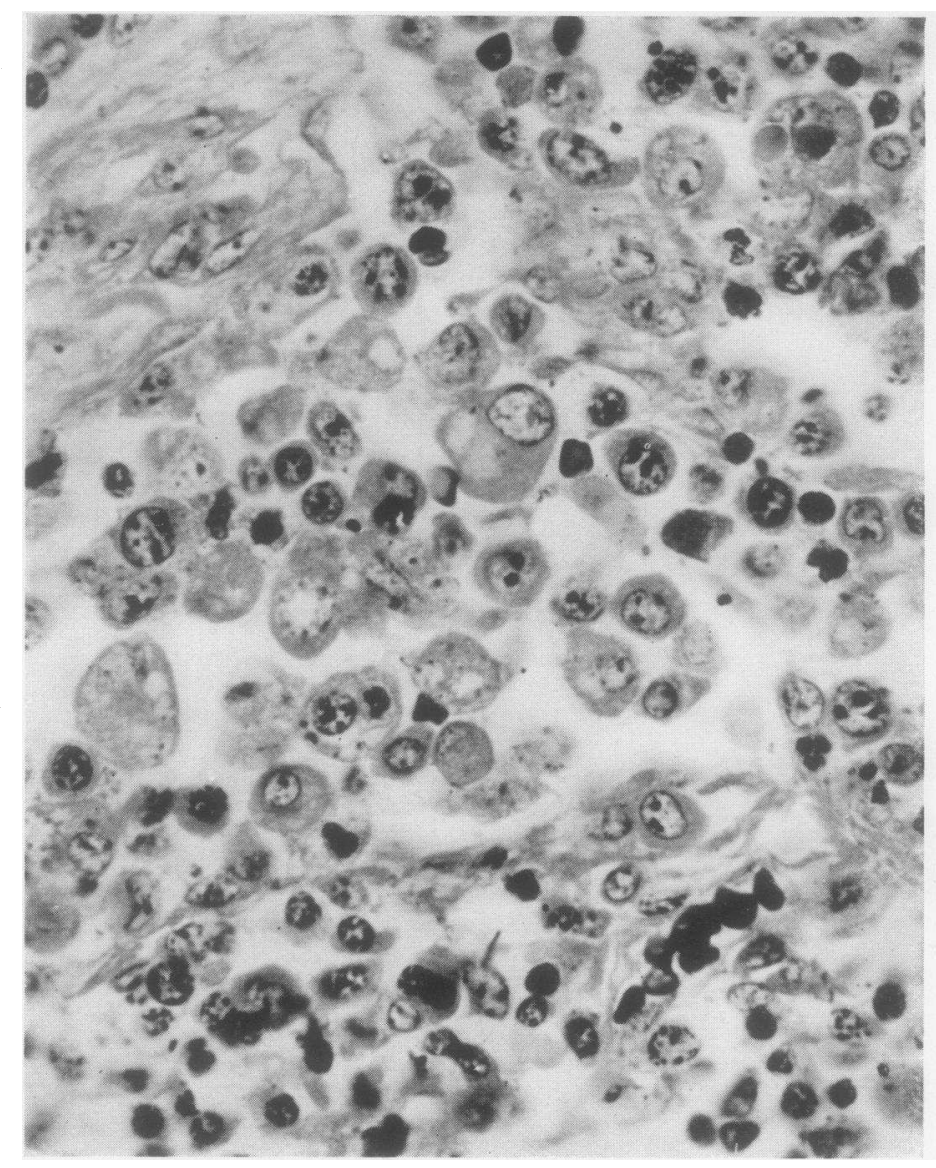

Figure 5. Case P. B. Lobar Pneumonia. Pneumococcus Group IV. U. of C., Hospital Number 97361. Section of Lymph Node from Hilum of Right Lower Lobe Showing Marked MacroPHAGE REACTION. $\times 700$.

The lesion in the lung-approximately 4 days old-exhibited no response of the macrophages.

response. After this period, however, the proportion of lesions showing this change was markedly increased. Among 47 lesions ranging from 5 to 12 days in age 32 exhibited a macrophage reaction, and in 19 of these the response was well developed (Table II).

It will be noted in Table $I$ that until the stage when some of the lesions began to show a well developed macrophage reaction (5th day) the intra-alveolar exudate was predominantly polymorphonuclear in nature. Even after the 5th day the great majority of the lesions showed this same cellular picture, and it was not until the 10th day that the macrophage became the predominant cell of the exudate.
TABLE II

Relationship of macrophage reaction to resolution

\begin{tabular}{|c|c|c|c|c|c|c|}
\hline \multirow{2}{*}{$\begin{array}{c}\text { Stage of } \\
\text { disease }\end{array}$} & \multirow{2}{*}{$\begin{array}{l}\text { Age of } \\
\text { lesions }\end{array}$} & \multirow{2}{*}{$\begin{array}{c}\text { Number } \\
\text { of } \\
\text { lesions }\end{array}$} & \multicolumn{2}{|c|}{$\begin{array}{l}\text { Macrophage } \\
\text { reaction }\end{array}$} & \multirow{2}{*}{$\begin{array}{l}\text { Number } \\
\text { showing } \\
\text { resolu- } \\
\text { tion }\end{array}$} & \multirow{2}{*}{$\begin{array}{l}\text { Number } \\
\text { showing } \\
\text { resolution } \\
\text { without } \\
\text { macrophage } \\
\text { reaction }\end{array}$} \\
\hline & & & $\begin{array}{l}\text { Begin- } \\
\text { ning }\end{array}$ & $\begin{array}{c}\text { Well } \\
\text { devel- } \\
\text { oped }\end{array}$ & & \\
\hline Active & $\begin{array}{l}1 \text { st } 24 \text { hours } \\
1 \text { to } 4 \text { days } \\
5 \text { to } 8 \text { days } \\
9 \text { to } 12 \text { days }\end{array}$ & $\begin{array}{l}13 \\
26 \\
30 \\
17\end{array}$ & $\begin{array}{r}4 \\
11 \\
13 \\
3\end{array}$ & $\begin{array}{r}0 \\
0 \\
6 \\
13\end{array}$ & $\begin{array}{r}0 \\
0 \\
10 \\
15\end{array}$ & $\begin{array}{l}0 \\
0\end{array}$ \\
\hline $\begin{array}{c}\text { After } \\
\text { recovery }\end{array}$ & $\begin{array}{l}1 \text { to } 2 \text { weeks } \\
1 \text { to } 2 \text { months }\end{array}$ & $\begin{array}{l}3^{*} \\
3^{*}\end{array}$ & $\begin{array}{l}\mathbf{0} \\
\mathbf{0}\end{array}$ & $\begin{array}{l}3 \\
3\end{array}$ & $\begin{array}{l}3 \\
3\end{array}$ & $\begin{array}{l}0 \\
0\end{array}$ \\
\hline
\end{tabular}

* Three cases.

Although a beginning macrophage reaction was not infrequently observed in the first four days 
of the pathological process, resolution of the lesion was not encountered until the fifth day. After this time the percentage of lesions showing resolution increased progressively with the age of the process (Table II). In lesions more than eight days old resolution was found to be taking place in 15 of 17 instances. In no case was resolution observed in the absence of the macrophage reaction.

\section{Macrophage reaction in the lungs after recovery}

Sections were obtained from six patients dying at intervals of six days to two months following recovery from lobar pneumonia. Death was due in four instances to complications caused by the pneumococcus, endocarditis, empyema and menin- gitis. One patient died of nephritic uremia and one of a necrotic cellulitis and a diffuse pneumonia (streptococcus and staphylococcus) following tracheotomy.

A pronounced macrophage reaction was found in all six cases (Tables I and II). Figure 6 is taken from the right upper lobe of the patient dying with nephritic uremia six days after recovery. This is fairly typical of the findings in the other cases but shows fewer macrophages in the air spaces than often observed. In three of the cases there was a recent complicating irregular pneumonia as indicated by collections of well preserved polymorphonuclear leukocytes and the presence of streptococci, staphylococci or both. Only one of these three showed pneumococci.

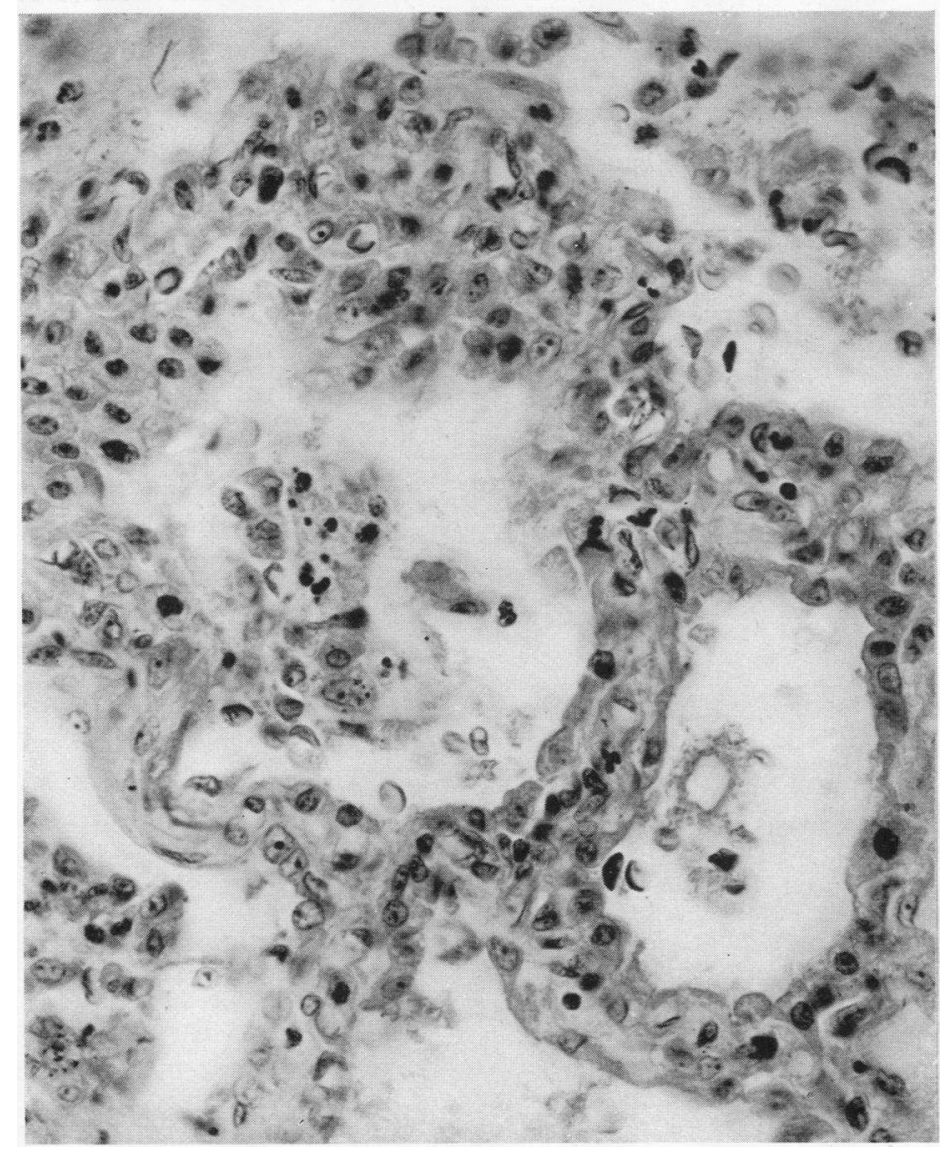

Figure 6. Case R. R. Lobar Pneumonia. Pneumococcus Group IV. U. of C., Hospital Number $61418 . \times 450$.

Patient died of nephritic uremia six days after clinical recovery from lobar pneumonia. Section of right upper lobe in a state of advanced resolution. Shows marked mobilization of macrophages. 
TABLE III

Relationship of macrophage reaction to distribution of pneumococci

\begin{tabular}{|c|c|c|c|c|c|c|c|c|}
\hline \multirow{2}{*}{ Stage of disease } & \multirow{2}{*}{ Age of lesion } & \multirow{2}{*}{\multicolumn{2}{|c|}{$\begin{array}{l}\text { Number of lesions showing different } \\
\text { degrees of macrophage reaction }\end{array}$}} & \multicolumn{3}{|c|}{$\begin{array}{l}\text { Number of pneumococci } \\
\text { in lesion }\end{array}$} & \multicolumn{2}{|c|}{$\begin{array}{l}\text { State of } \\
\text { pneumococci }\end{array}$} \\
\hline & & & & Many & Few & Absent & $\underset{\text { free }}{\text { Mostly }}$ & $\begin{array}{l}\text { Mostly } \\
\text { intra- } \\
\text { cellular }\end{array}$ \\
\hline \multirow[t]{4}{*}{ Active } & 1 st 24 hours & $\begin{array}{l}\text { No reaction } \\
\text { Beginning reaction } \\
\text { Well developed reaction }\end{array}$ & $\begin{array}{l}9 \\
4 \\
0\end{array}$ & $\begin{array}{l}7 \\
2\end{array}$ & $\begin{array}{l}2 \\
2\end{array}$ & $\begin{array}{l}0 \\
0\end{array}$ & $\begin{array}{l}8 \\
3\end{array}$ & $\begin{array}{l}1 \\
1\end{array}$ \\
\hline & 1 to 4 days & $\begin{array}{l}\text { No reaction } \\
\text { Beginning reaction } \\
\text { Well developed reaction }\end{array}$ & $\begin{array}{r}15 \\
11 \\
0\end{array}$ & $\begin{array}{l}15 \\
11\end{array}$ & $\begin{array}{l}0 \\
0\end{array}$ & $\begin{array}{l}0 \\
0\end{array}$ & $\begin{array}{l}1 \\
2\end{array}$ & $\begin{array}{r}14 \\
9\end{array}$ \\
\hline & 5 to 8 days & $\begin{array}{l}\text { No reaction } \\
\text { Beginning reaction } \\
\text { Well developed reaction }\end{array}$ & $\begin{array}{r}11 \\
13 \\
6\end{array}$ & $\begin{array}{r}10 \\
9 \\
0\end{array}$ & $\begin{array}{l}1 \\
4 \\
3\end{array}$ & $\begin{array}{l}0 \\
0 \\
3\end{array}$ & $\begin{array}{l}1 \\
0 \\
0\end{array}$ & $\begin{array}{r}10 \\
13 \\
3\end{array}$ \\
\hline & 9 to 12 days & $\begin{array}{l}\text { No reaction } \\
\text { Beginning reaction } \\
\text { Well developed reaction }\end{array}$ & $\begin{array}{r}1 \\
3 \\
13\end{array}$ & $\begin{array}{l}1 \\
3 \\
0\end{array}$ & $\begin{array}{l}0 \\
0 \\
8\end{array}$ & $\begin{array}{l}0 \\
0 \\
5\end{array}$ & $\begin{array}{l}0 \\
0 \\
0\end{array}$ & $\begin{array}{l}1 \\
3 \\
8\end{array}$ \\
\hline \multirow[t]{2}{*}{ Following recovery } & 1 to 2 weeks & $\begin{array}{l}\text { No reaction } \\
\text { Beginning reaction } \\
\text { Well developed reaction }\end{array}$ & $\begin{array}{l}0 \\
0 \\
3\end{array}$ & 0 & 1 & 2 & 0 & 1 \\
\hline & 1 to 2 months & $\begin{array}{l}\text { No reaction } \\
\text { Beginning reaction } \\
\text { Well developed reaction }\end{array}$ & $\begin{array}{l}0 \\
0 \\
3\end{array}$ & 0 & 0 & 3 & & \\
\hline
\end{tabular}

No microorganisms were detected in the lung lesions of the other three cases (Table III).

Relationship of the macrophage reaction to the distribution of pneumococci

In studying the distribution of pneumococci in the lesions, an attempt was made to distinguish between those showing large numbers of microorganisms and those showing few, as well as to estimate whether most of the pneumococci present were within or without the leukocytes. Since any strictly quantitative determination was not feasible, a rough estimate was made of the number of pneumococci present in the different parts of the section or sections from each lesion. If the average number of microorganisms per field did not exceed 10 it was designated as "few." Numbers greater than this were classified as "many." Actually the differentiation between the lesions tabulated as showing few pneumococci and those showing many was simple, since the great majority of the former revealed considerably less than 10 organisms per field-often only one or two in several fields-while in the latter group scores to hundreds of pneumococci were usually present.
Similarly, a judgment as to whether most of the pneumococci were intra or extracellular was easily arrived at in most instances. In a few cases prolonged examination was required for this purpose. In lesions showing a fairly uniform type of cellular exudate, the majority of those studied, the numbers and distribution of pneumococci from area to area was fairly constant. This was quite otherwise when more than one stage of the pathological process was represented in a single section. Such changes as were observed at the spreading margin of a young lesion or in an area of focal resolution were attended by marked and characteristic modifications in the state and number of the microorganisms present.

The data obtained from a study of the distribution of pneumococci by the method described above are presented in Tables I and III. It was found that pneumococci were present in large numbers in the great majority of the lesions up to the seventh day (Table I). While 4 of the 11 twenty-four hour metastatic lesions showed few pneumococci, all of the 26 , one to four day processes, were characterized by the presence of many microorganisms. From the fifth day onward a cer- 
tain percentage of the lesions contained few pneumococci, and after the ninth day only one out of eleven showed many; in the other ten microorganisms were few or absent. During the first twenty-four hours of the evolving inflammatory process, the pneumococci were, for the most part, free in the edema fluid. After this stage they were observed to be principally within the phagocyting cells. In many cases very few or no extracellular pneumococci could be found. Pneumococci were present in the greatest abundance in the lesions of patients showing marked bacteremia at death. In such cases they could be frequently observed in the process of liberation from disintegrating polymorphonuclear leukocytes.

It will be noted in Table I that with the increase in the proportion of lesions exhibiting a well developed macrophage reaction there is a cor- responding diminution in the number of pneumococci. This relationship is brought out more directly in Table III where it will be seen that lesions showing few or no pneumococci are, with one exception, classified under "beginning" or "well developed macrophage reaction." Disappearance of pneumococci occurred only when the macrophage reaction was well advanced. Perhaps of even more significance than the tabulated results are the findings in individual cases exhibiting lesions of widely varying ages. Figures 7 and 8 are taken from two different lobe lesions of $\mathrm{Pa}$ tient J. D. D., U. of C., Hospital Number 30016, dying on the 7th day of a lobar pneumonia due to Pneumococcus Type VIII. Figure 7 shows an area in the left lower lobe which had become involved only 24 to 36 hours before death. The inflammatory process consisted of alternating

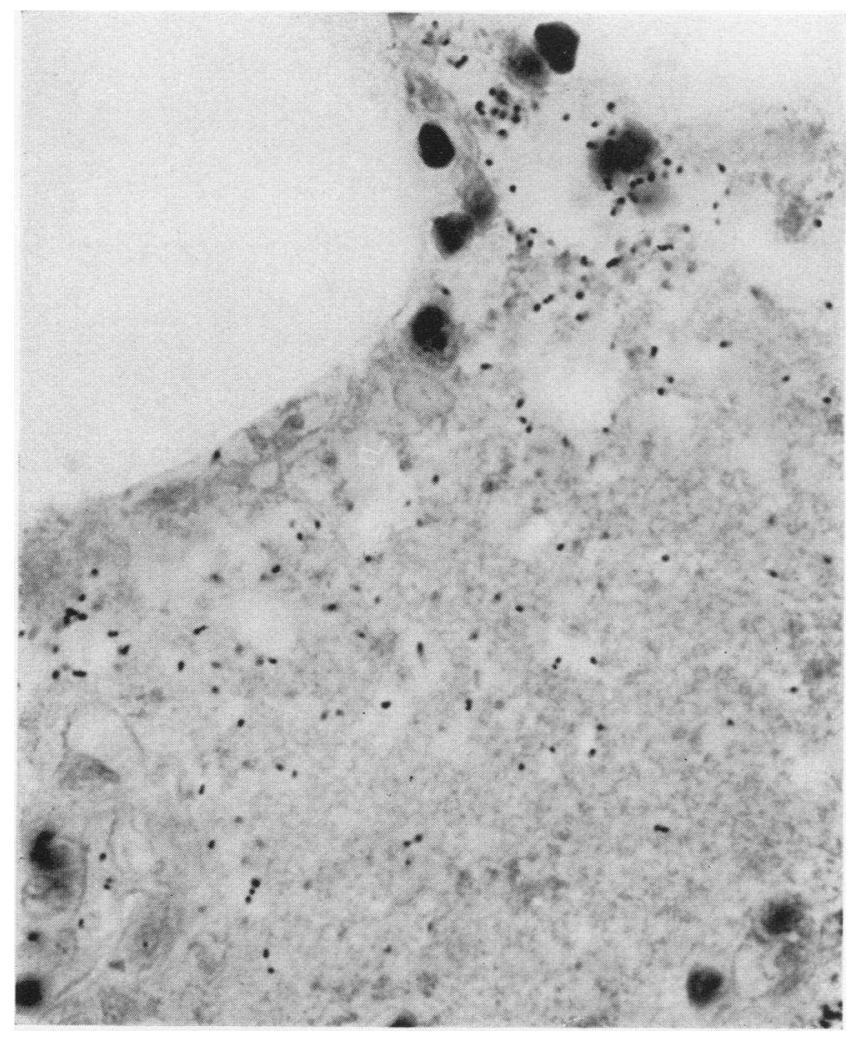

Figure 7. Case J. D. D. Lobar Pneumonia. Pneumo- coccus Type ViII. U of C., Hospital Number 30016. Section of Left Lower Lobe Which Became Involved 24 to 36 Hours before Death. $\times 1000$.

Large numbers of pneumococci are present free in edemafilled alveoli. 


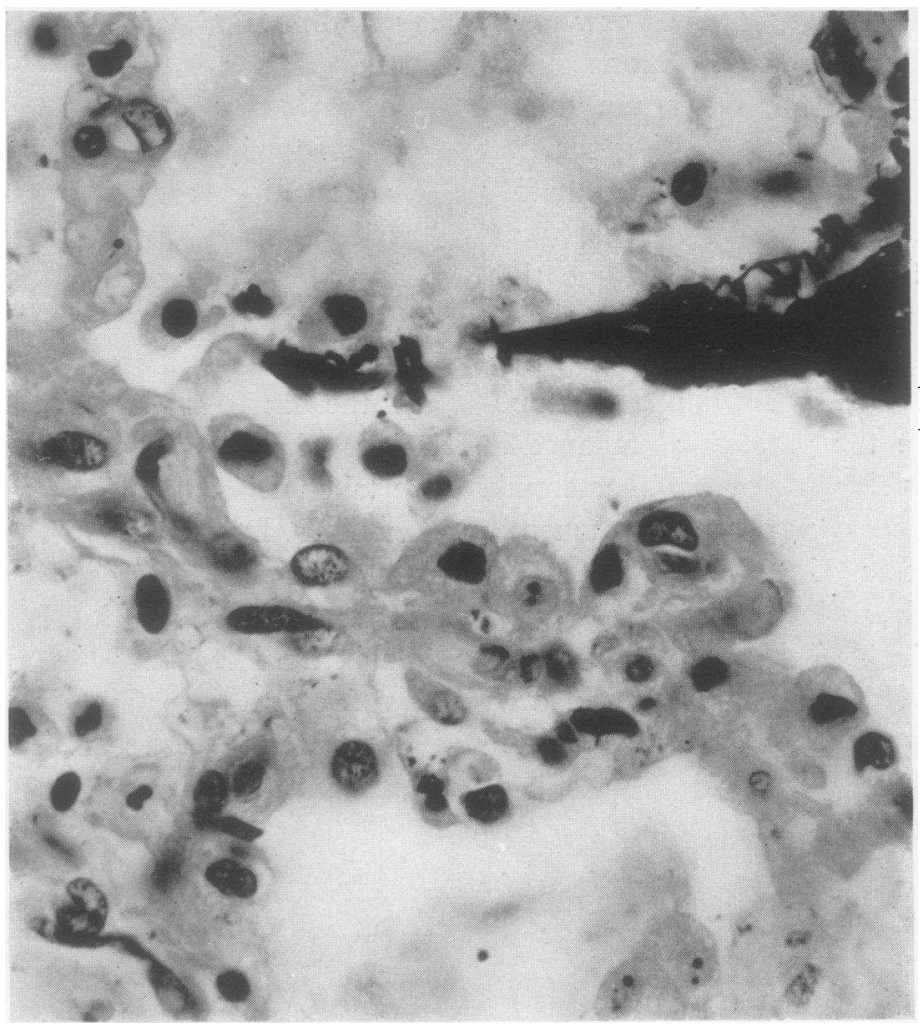

Figure 8. Case J. D. D. Section of Right Upper Lobe Which is Undergoing Resolution. $\times 700$.

Marked macrophage reaction present and no pneumococci detectable.

areas of edema and polymorphonuclear leukocytic exudation. Great numbers of pneumococci were present all through the lesion. Figure 8 is made from a section of the right upper lobe which was the site of the initial lesion. The lobe was found to be in a state of resolution and showed a marked macrophage reaction. Very few pneumococci were detected, and these were all intracellular. None are clearly seen in the microphotograph. Analogous instances were repeatedly observed in the course of the present study.

Other evidences of the local disappearance of pneumococci with the appearance of the macrophages were found in closely adjacent areas in the same lobe lesion. One of the most striking examples of this change is shown in microphotographs, Figures 9 and 10, which were made from the inflamed pleura of the left lower lobe which had become involved ten days before death and showed a well developed macrophage reaction.
At the inner margin of the pleura, macrophages were concentrated in considerable numbers, and no pneumococci could be detected (Figure 9), while at the distance of only one high power field toward the periphery, pneumococci were present in large numbers in a cellular exudate which consisted almost entirely of polymorphonuclear leukocytes (Figure 10).

\section{Phagocytic activity of the macrophages}

The constant finding of diminishing numbers of pneumococci in the presence of an increasing concentration of macrophages brings up the question as to the mode of disappearance of these microorganisms. Is the observed phagocytic activity of the macrophages sufficient to account for the phenomenon? While it is not possible to give an unequivocal answer to this question, detailed study of a large number of sections from lesions show- 

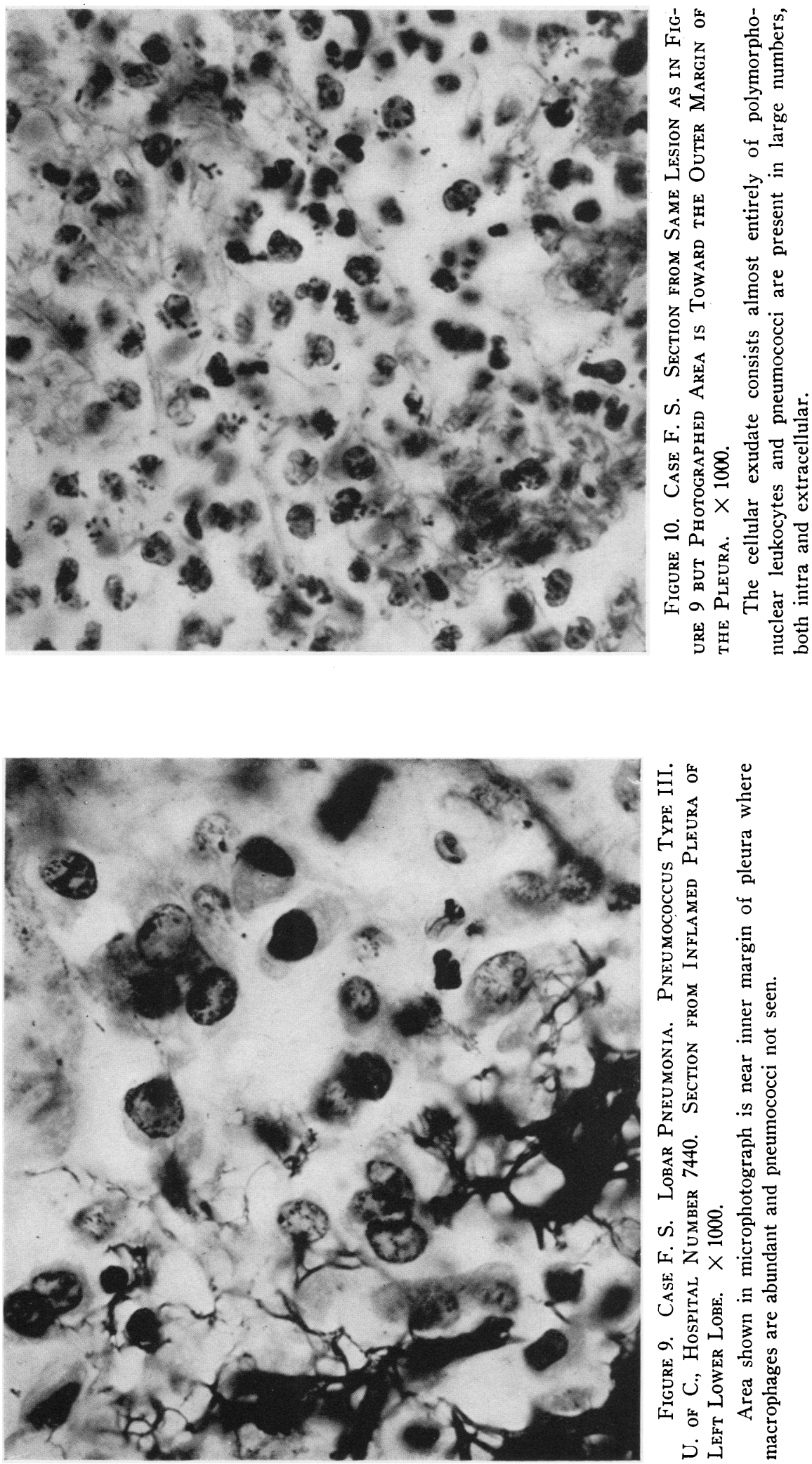
ing all stages of the macrophage reaction reveal the fact that the macrophages are capable of engulfing and digesting large numbers of pneumococci. The most active phagocytosis was observed where macrophages were first appearing in heavily infected regions. Scores of organisms could be counted not infrequently within a single cell. Figure 11 shows macrophages in such an area. positive dots. The effective intracellular digestive power exhibited by the macrophages was in sharp contrast to that shown by many of the surrounding polymorphonuclear leukocytes. The latter cells containing well preserved pneumococci were frequently observed in the immediate neighborhood of macrophages filled with partially digested forms. The numbers of polymorphonuclear leukocytes

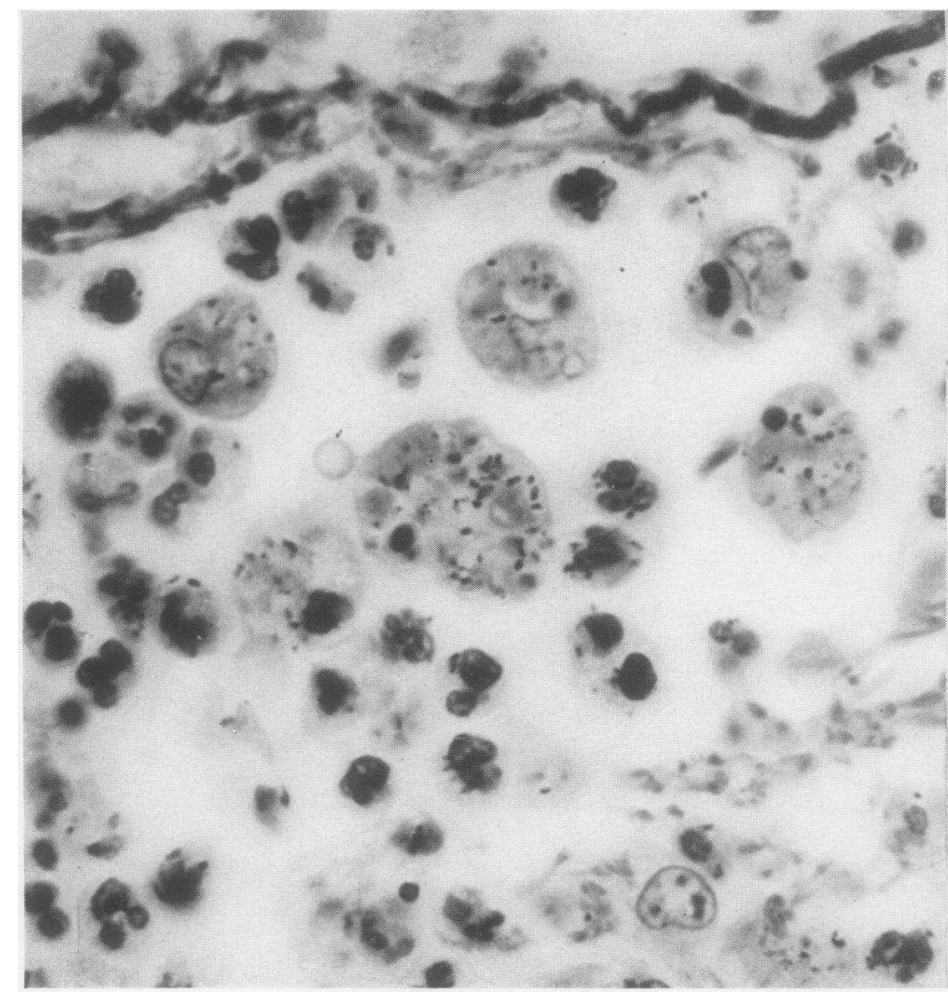

Figure 11. Case H. C. B. Lobar Pneumonia. Pneumococcus Group IV. U of C., Hospital Number 45257. Section from Right Lower Lobe in Stage of Gray Hepatization and Focal Beginning Resolution. $\times 1100$.

Macrophages are seen to be actively phagocytic, containing pneumococci, polymorphonuclear leukocytes and red blood cells.

On the contrary, in regions in which the macrophage was the predominant cell usually few or no intracellular pneumococci could be detected. Transitional stages from the early to the well developed macrophage response, and this could be occasionally seen in the same section, revealed the progressive disappearance of the engulfed microorganisms. They appeared to melt away, frequently collected in vacuoles, and in the final stage of digestion were represented by minute gram observed within the macrophages could account for the disappearance of a considerable proportion of these cells from the exudate. The leukocytes and their contained pneumococci appear to be destroyed effectively and rapidly by the macrophages. With rare exception the macrophages were not observed to be phagocytic until they had become detached from the alveolar walls. No evidence of extracellular destruction of pneumococci could be detected. 
The finding of clear zones surrounding macrophages distributed in fibrin masses suggests that they exert some kind of lytic action on this material. Since the effect of this action is apparent only in the absence of fibrin in the immediate neighborhood of the cell, such an effect is purely an assumption.

\section{Lobar pneumonia due to microorganisms other than the pneumococcus}

A study was also made of 17 lobe lesions 'secured from 8 cases of pneumonia due to the hemolytic and non-hemolytic streptococcus, the staphylococcus and the gonococcus. The inflammatory processes in some instances were strikingly similar to those produced by the pneumococcus, in others, notably lesions caused by the staphylococcus and gonococcus, they were atypical and irregularly distributed. It may be stated briefly that the histological changes in respect to the macrophages were in general similar to those already described. The macrophage reaction appeared in its well developed form in the older lesions and was accompanied by resolution and a diminution in the number of microorganisms present. In only half the cases, however, were two or more lesions of different age obtained, and it may be that a larger series would reveal differences from the pneumococcus pneumonias. The two cases of pneumonia associated with gonococcus bacteremia presented a striking picture of macrophage response all through the lesions. The age of the pneumonic processes in these individuals could not be determined.

\section{DISCUSSION}

In a previous study of the development of acquired humoral immunity during the course of lobar pneumonia (12) it was found that although circulatory immune substances were demonstrable in every patient recovering from the disease, only an irregular sequential relationship between these newly acquired serum properties and the termination of the disease could be detected. This finding, together with the occasionally observed regional clearing of the lesion during the active stage of the disease, and the occurrence of focal resolution of the pneumonic process frequently seen at postmortem, suggested the possibility that recovery might depend on the cooperation of a local cellular reaction and specific immune substances. Do the observations on the mobilization and transformation of the macrophages which we have described in this study indicate such a reaction of the local tissue cells? Before attempting to answer this question consideration must be given to certain other queries raised by the results of our study, viz: (1) Does the fact that the macrophage reaction was observed in the majority of the lesions more than eight days of age (16 out of 17 ; see Table II) indicate that this is the regular sequence of cellular change in the pathogenesis of the process, or are we to infer that most pneumonic lesions tend to heal, provided the patient lives long enough? (2) Does the number of pneumococci in the inflammatory area tend to diminish with the age of the lesion, independent of the macrophage reaction, or is a fatal outcome associated with the persistence of large numbers of microorganisms in the lungs? A review of the data pertinent to this second question largely supplies an answer to both. We have observed that pneumococci may survive in the consolidated lung, and apparently multiply, as judged by their numbers and state, in lesions from 9 to 12 days of age showing no response of the macrophages or only a beginning one (Tables I and III), whereas lesions exhibiting a well developed macrophage reaction at a similar or much younger age were regularly characterized by a relative infrequence or absence of microorganisms. In all but one of our cases, which was exceptional in several respects, ${ }^{5}$ large numbers of pneumococci were detected in some part of the lung at death, most often in recent spreads and always in areas show-

\footnotetext{
5 This patient (B. B., U. of C., Hospital Number 62204) had an extensive bilateral involvement, with marked anoxemia. Several days before death, which occurred on the 11th day of the disease, the patient showed immune substances in the blood and sterile blood cultures. Postmortem revealed most of the lung in a state of resolution. Even where polymorphonuclear leukocytes predominated pneumococci were few and all intracellular, which suggests that when an adequate concentration of immune substances are present, the polymorphonuclear leukocytes can deal with the pneumococci effectively, just as is observed in the experimental pneumonia in the dog and in vitro experiments with serumleukocyte mixtures. Death in this case can be attributed largely to anoxemia.
} 
ing little or no mobilization of the macrophages. These findings, combined with the observation that this characteristic cellular change precedes and always accompanies resolution, afford good evidence that it is closely associated with healing of the lesion. But as to whether the cellular changes occurring in the consolidated lung during recovery from the disease are identical with those observed in the resolving lung at postmortem, our study provides no data except that of the marked macrophage response seen in the lung of a patient dying 6 days after recovery. Recently, however, Curphey (13) has secured direct evidence on this subject by means of biopsies made on the lungs of patients during the course of lobar pneumonia. He showed that the same cellular reactions which we have described in the resolving lung after death occur during recovery from the disease. Thus Curphey's important findings have provided the evidence which bridges our observations in the experimental disease with those in human beings.

At this point, the question of the relationship of resolution to the recovery from the disease will undoubtedly be asked. If we assume that resolution represents local healing, why is it that occasionally parts of the lung remain consolidated for varying periods of time after the patient has made a clinical recovery? Unfortunately, our autopsy material does not include any undoubted cases of delayed resolution of this type, and until such histological data is available, we can only make surmises as to why the inflammatory exudate persists. Since the beginnings of the macrophage reaction can be detected before there is any sign of resolution, may it not be possible that the evolution of the process is inhibited at some point prior to the stage of removal of the exudate, but not before the effective control of the invading microorganisms has been accomplished? We have abundant evidence both from physical findings and $x$-ray films that resolution of the pneumonic process after recovery proceeds very unevenly (14). In some cases, clearing of the whole area of consolidation takes place uniformly and rapidly, and is complete within a few days, while in other instances resolution is of a patchy nature, parts of the involved lung remaining infiltrated for weeks or longer. In our histological study we have observed frequently areas in which macrophages were quite abundant in the exudate, and pneumococci few and entirely intracellular, yet little evidence of resolution of the exudate could be detected. It is also conceivable that the process which initiates resolution in one part of the lesion may, if the conditions are favorable, exert its effects on the other parts of the lesion still in the active stage. The case B. B., cited in the footnote above, illustrates this possibility.

While the evidence presented thus far suggests the probability that the macrophage reaction represents an immune response to the pneumococcus, it is by no means complete or conclusive. The observed active phagocytosis and complete digestion of pneumococci on the part of the macrophages in contrast to the apparent inability of the polymorphonuclear leukocytes to destroy the ingested microorganisms after a certain stage in the inflammatory process, might signify that some unknown factor has so changed the pneumococci that they can be readily disposed of by the freshly mobilized macrophages. Again, the occurrence of a beginning macrophage reaction observed in many young metastatic lesions arising late in the disease and associated with the presence of many pneumococci, seems at first difficult to correlate with our other data. However, the response of the macrophages in these instances was uniformly minimal in nature and perhaps represented a final effort of the body to combat an overwhelming bacterial invasion. It is also possible that many of these cells were immature. As was pointed out earlier, phagocytosis of the macrophages was rarely observed until they had entered the alveolar spaces.

When considered in the light of our findings in experimental pneumonia in the dog, the foregoing observations in human beings assume more significance. In the experimental disease, resolution of the lesion and recovery from the disease appear to be constantly associated and accompanied by the characteristic mobilization of the macrophages. That this reaction is indicative of acquired antipneumococcal immunity was brought out by histological changes observed in recurrent pneumonic lesions produced at varying intervals following recovery from the primary or previous attack. In such lesions, especially those occupying the site of the antecedent inflammation, the macro- 
phage reaction occurred very early, often within 6 to 12 hours after the inception of the infection and was accompanied by a rapid sterilization of the lesion. Further experimental observations on the association of the macrophage reaction with regional healing preceding recovery from the disease will be presented in a forthcoming paper.

Neither in our studies on the experimental canine pneumonia nor in the human disease has it been possible to discover a constant relationship between the appearance of circulatory immune substances and the development of the macrophage reaction in the lung lesion. This does not necessarily signify that the macrophages carry on their antipneumococcal activity independent of humoral immunity. Recent studies, especially those of Lucké, Strumia, Mudd, et al. (15), indicate that normal macrophages, at least, are just as dependent on the assistance of opsonins for effective phagocytosis as are polymorphonuclear leukocytes. However, it does suggest that if immune substances are necessary for the adequate functioning of the macrophages, either they are present in the blood in concentrations too low for our methods of detection, or they are produced locally in the lung.

A discussion of the origin of the macrophages present in the pulmonary lesions of lobar pneumonia should be prefaced by the statement that we know of no conclusive evidence on this subject. An excellent review of the literature is contained in Costa's paper (9). Our study of the various stages of the evolution of the macrophage reaction, both in the human being and the dog, points to a local origin for the majority of the large phagocytic cells. This view was advanced by Pratt (4) thirty-five years ago, and has been advocated by Fried (16) and Costa (9) in recent publications. Costa believes, and his evidence seems good, that part of the macrophages at least go through a monocytoid phase in their development. Certain of our findings in the clinical disease process indicate, on the other hand, that macrophages may be mobilized from areas outside the immediate alveolar unit. Several instances were observed in which the lesion exhibited an intra-alveolar exudate predominantly macrophagic in composition without any reaction of the septa. These cells were chiefly "dust cells," and transport to this area was suggested by their relative infrequence in other uninvolved parts of the lung. Another possible source of macrophages other than the alveolar walls was suggested by the occasional finding of nests of the macrophage type of cell occurring in areas of lymphoid tissue near blood vessels or bronchi. The appearance of these lymphoid areas was similar to that of the hilum lymph nodes showing a macrophage reaction. We have also observed large mononuclear cells apparently arising from the endothelium of the lung capillaries-Mallory's “ endothelial leukocytes." Permar (17) considers this to be the locus of origin of the mononuclear phagocytes of the lung. Foot (18) believes that they arise from the monocytes of the blood. We have no information as to whether or not macrophages may be brought from extra pulmonary foci. Large mononuclears of the macrophage type have been observed but rarely in the blood vessels of the resolving lung. ${ }^{6}$

\section{SUMMARY}

A histological study was made of postmortem tissues obtained from 40 cases of lobar pneumonia representing over 90 separate lobe lesions of approximately known age, with the purpose of ascertaining whether or not the macrophages play as conspicuous a rôle in the later stages of the human pathological process as was observed in the lesion of experimental lobar pneumonia in the dog. It was found that resolution of the consolidated lung was regularly accompanied by characteristic changes in the lung parenchyma and cellular exudate analogous to those occurring in the dog's lung at the time of recovery. The evolution of the whole process could be followed often in a single case where lesions of different ages were present. The first evidence of the reaction consists of an increase in the number of large mononuclear cells in the alveolar walls, many of which protrude into the air spaces. This re-

6 The increased percentage of monocytes appearing in the peripheral blood of patients recovering from lobar pneumonia, first described by Hickling (19), may indicate a general cellular reaction to the pneumococcus. This change is not observed in fatal cases even though a local macrophage reaction is occurring in some part of the lung. But as to whether the monocyte represents a youthful stage of the macrophage or is a distinct cell type, opinions differ. 
sults in a thickening of the septa. As the process develops, the large mononuclear cells become detached from the alveolar wall and enter the exudate where they exhibit the form and phagocytic functions of the macrophages. These cells gradually replace the polymorphonuclears, the fibrin disappears progressively, and the lesion assumes the characteristic appearance of resolution. The same type of tissue cell reaction was observed in the lymph glands at the hilum of the lung.

Sections obtained from six patients dying at intervals of six days to two months following recovery from lobar pneumonia showed a pronounced macrophage reaction in every instance.

The most striking finding in the study of these human tissues was that wherever a well developed macrophage reaction occurred, pneumococci were observed to be few in number or absent, while in the great majority of lesions of all ages in which the exudate was composed predominantly of polymorphonuclear leukocytes, microorganisms were abundant. Such marked differences in numbers of pneumococci were observed not only between lobe lesions but also at times in different parts of the same lesion where areas of focal macrophage reaction were occurring. The macrophages were seen to be actively phagocytic and showed evidence of effective digestion of the engulfed pneumococci.

While the data derived from this study do not permit of definite conclusions concerning the rôle played by the macrophage reaction in the mechanism of recovery from lobar pneumonia, when viewed in the light of various relevant observations in the experimental disease in the dog, they do suggest that mobilization of the macrophages represents an immune response of the pulmonary tissue cells.

\section{BIBLIOGRAPHY}

1. Robertson, O. H., Coggeshall, L. T., and Terrell, E. E., Experimental pneumococcus lobar pneumonia in the dog. II. Pathology. J. Clin. Invest., 1933, $12,433$.

2. Coggeshall, L. T., and Robertson, O. H., A study of repeated attacks of experimental pneumococcus lobar pneumonia in dogs. J. Exper. Med., 1935, 61, 213.
3. Robertson, O. H., Coggeshall, L. T., and Terrell, E. E., Experimental pneumococcus lobar pneumonia in the dog. III. Pathogenesis. J. Clin. Invest., 1933, $12,467$.

4. Pratt, J. H., The histology of acute lobar pneumonia. Johns Hopkins Hosp. Rep., 1900, 9, 265.

5. Mallory, F. B., Principles of Pathologic Histology. W. B. Saunders Company, Philadelphia, 1920, p. 473.

6. Loeschcke, H., Untersuchungen über die Kruppöse Pneumonie. Beitr. z. path. Anat. u. z. allg. Path., 1931, 86, 201.

7. Fried, B. M., The lungs and the macrophage system. Arch. Path., 1934, 17, 76.

8. Fried, B. M., Allergic inflammation of the lungs. The pathogenesis of lobar pneumonia. Arch. Path., 1934, 18, 865.

9. Costa, A., Monociti e istiociti nella polmonite crupale. Sperimentale, Arch. de biol., 1934, 88, 126.

10. Hodges, P. C., and Lipscomb, T. H., Stereoscopic roentgenography of bedridden pneumonia patients. J. Lab. and Clin. Med., 1935, 20, 357.

11. Wallace, H. M., A stain for fibrin, gram postive bacteria and basal bodies in tissues. Science, 1931, 74, 369.

12. Robertson, O. H., Graeser, J. B., Coggeshall, L. T., and Harrison, M. A., The relation of circulating antipneumococcal immune substances to the course of lobar pneumonia. II. Acquired immune substances. J. Clin. Invest., 1934, 13, 633.

13. Curphey, T. J., A preliminary report on intra vitam biopsy studies of the pathogenesis of pneumococcus lobar pneumonia. Am. J. Path. (Abstract), 1935, 11, 861.

14. Graeser, J. B., Wu, C., and Robertson, O. H., Physical signs and roentgenographic findings in lobar pneumonia in adults. Arch. Int. Med., 1934, 53, 249.

15. Lucké, B., Strumia, M., Mudd, S., McCutcheon, M., and Mudd, E. B. H., On the comparative phagocytic activity of macrophages and polymorphonuclear leucocytes. The essential similarity of tropin action with respect to the two types of phagocyte. J. Immunol., 1933, 24, 455.

16. Fried, B. M., The defensive and metabolic apparatus of the lungs. Arch. Path., 1928, 6, 1008.

17. Permar, H. H., An experimental study of the mononuclear phagocytes of the lung. J. Med. Res., 1920, 42, 9.

The mononuclear phagocytes in experimental pneumonia. J. Med. Res., 1923-24, 44, 27.

18. Foot, N. C., Studies on endothelial reactions. X. On the origin of the pulmonary "Dust cell." Am. J. Path., 1927, 3, 413.

19. Hickling, R. A., The monocytes in pneumonia. A clinical and hematologic study. Arch. Int. Med., 1927, 40, 594. 